Tarih Kültür ve Sanat Araştırmaları Dergisi

Revue des Recherches en Histoire Culture et Art مجلة البحوث التاريخية و الثقافية والفنية
Vol. 7, No. 2, June 2018

Copyright (C) Karabuk University

http://kutaksam.karabuk.edu.tr

\title{
DOI: 10.7596/taksad.v7i2.1480
}

Citation: Özsavaş Akçay, A., \& Alothman, H. (2018). Fashion Inspired by Architecture: The Interrelationship between Mashrabiya and Fashion World. Journal of History Culture and Art Research, 7(2), 328-351. doi:http://dx.doi.org/10.7596/taksad.v7i2.1480

\section{Fashion Inspired by Architecture: The Interrelationship between Mashrabiya and Fashion World}

\author{
Ayten Özsavaş Akçay¹, Hiba Alothman²
}

\begin{abstract}
The relationship between architecture and fashion fields have received many studies. Some researches have considered them as parallel worlds, while others have proven that the link is an interrelationship. Generally, architecture and fashion have many common sources: art, science, and technology. This makes them sometimes close worlds, and in many other cases, they are mixed. However, it is wise to assume that the best situation when one field becomes a source to another, and they support each other within a logical visible relationship. Architecture gives inspiration to fashion, per contra fashion achieves notability for an architectural figure or element.

Mashrabiya (The traditional Arab oriel window that works as an environmental architectural element) has entered into fashion field through one of the new approaches of the heritage restoration movement. This approach has presented unique fashion shows and unparalleled jewellery designs, while made Mashrabiya a popular name in non-architectural surroundings. While the environmental functions of Mashrabiya are used in many contemporary projects without acknowledging its original name "Mashrabiya". Moreover, other projects dealt with it using a new name like 'geometric panels', fashion has maintained the authenticity of the name and its orientalism. This article tries to show that Mashrabiya is one of the architectural element which gives inspiration to the fashion world. The article also presents examples of fashion and jewellery design inspired from the Mashrabiya element.
\end{abstract}

Keywords: Fashion, Mashrabiya, Geometric Panels, Architecture, Fashion in architecture, Architecture in fashion.

\footnotetext{
${ }^{1}$ Near East University, Faculty of Architecture, Department of Architecture Cyprus.

2 Phd.Student, Neart East University, Faculty of Architecture, Department of Architecture. E-mail: hiba.unique.design@gmail.com
} 


\section{INTRODUCTION:}

Each society needs to have its own expression which related to its values, principles and ethics. Architecture and fashion have been the ways to achieve that need. Talking about the Arab culture, it had always been characterized by decency and prudery, wherefore the world and films constantly offer a stereotype of the Arabs in heavy clothing without any details suggest the lightness in the style, like the facades of traditional Arab buildings which were extremely bare, and they had a solid and harsh impression due to the heavy walls. At this point as the different patterns of traditional Mashrabiya endued life and vibrancy to the ancient facades, modern Mashrabiya comes to play a refreshing role at the same level through a new approach in fashion and jewelry design which calls to express the Arab identity through fresh images.

Thenceforward, fashion according to fashion experts, it should reflect the person's personality, nature, lifestyle, temperament, if possible. And in the most popular way, it has become desirable to express identity.

"Fashion fades, only style remains the same." Coco Chanel (Craven, 2008).

Subsequently, keeping pace with fashion does not mean abandoning heritage or moving away from identity, but through adequate knowledge of the fixed past of the peoples, beside to the appreciation of their contemporary aspirations to express the lightness and movement, it becomes possible to provide a fashion with authentic style and spirited suited to our epoch.

Hence, the movement of introducing Arab identity into fashion starts within deliberate endeavors to use Mashrabiya patterns that express an original architectural element in Arab architecture, with reference to the original name "Mashrabiya" even for the hybrid designs. So, the name doesn't be marginalized as it happens in some contemporary architectural projects that benefit from Mashrabiya, but with replacing the name to "Geometric Panels". Thence, the combination of Mashrabiya and fashion has helped to preserve both the name and the revival of the heritage.

The research methodology of this paper deals with the relationship between architecture and fashion in general, pointing to the benefits and common points between them, since both fields reflect the image of the society and its identity. The research also shows how fashion achieves notability for architectural elements such as Mashrabiya and makes it a widespread name in non-architectural surroundings.

So as Mashrabiya supplies the buildings with good air movement to reduce the high temperature, modern version of Mashrabiya in fashion provides the character of lightness for the clothes, which in turn has given a sense of comfort and ease heat on the human body, beside to proving the Arab identity expression like aesthetic and social role of Mashrabiya does in architecture.

\section{THE RELATIONSHIP BETWEEN ARCHITECTURE AND FASHION}

A lot of studies confirm the fact that the architecture and fashion worlds have an interrelationship, they are not only two parallel worlds, but also integrated in numerous cases. Books, theses, articles, exhibitions and TV shows have discussed this issue. As well as numerous architects entering the world of fashion design, including rank names as Zaha Hadid. Along with there are many fashion designs inspired by famous architectural projects.

Both of fields depend on lines and shapes, they also deal with scales and norms related to the human body to create inventive forms, and generate structures and designs are related to the human being needs. Besides, working on highlight the aesthetic domain (Pugh et al, 2008). Hence, Coco Chanel provides an outline title for this merger when she said "Fashion is architecture. It is a matter of proportion." (Afzal, 2013) 
Later Calvin Klein who is considered as an important icon of the fashion industry, and he had done many amazing designs depending on the relationship between fashion and situation, fashion and the setting. And this setting can be either outdoor or indoor. It can really involve a lot of architecture, and this interconnection between fashion and architecture is something that has been a very important very special part of his work. Also, beyond the relationship between fashion and architecture is his own passion for architecture which he has demonstrated through a lot of specific projects. (Mostafavi, 2015)

Klein within his lecture on (The Role of Architecture in Fashion) at the Harvard Graduate School of Design, he spoke about that passion and how architecture related to his work, and building a brand and all the different things that he has done throughout his career. What he has done and how architecture, interior design, environment and landscape design play such an important role in his work. And he has always loved working with different architects. He pointed out also to some of clothes that he has made and relate to architecture, like a beautiful dress (Figure 1: a) which he focused on talking about how much he had loved the very sensual soft fabrics of it that move on a body, and that have structure, shape is inspired by architecture. And he described another shapely design with much love feeling. It was a coat that is wrapped and folded (Figure 2: b). In addition to many fashion designs which he had done were architectural as he defined them.

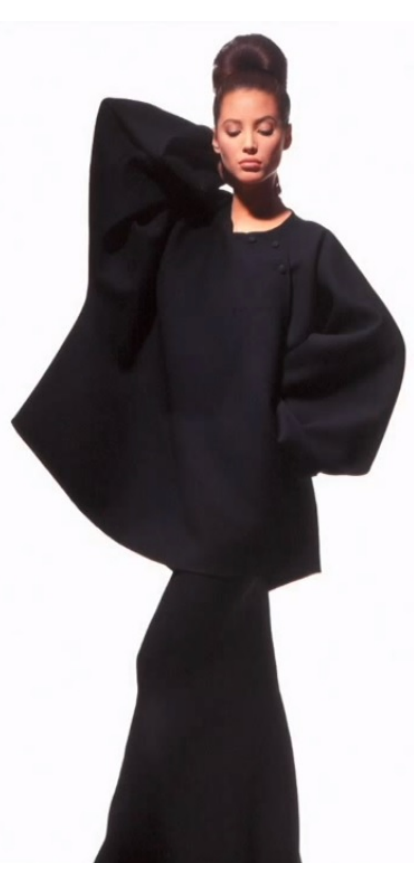

(a): A dress designed by Calvin Klein too relates to architecture.

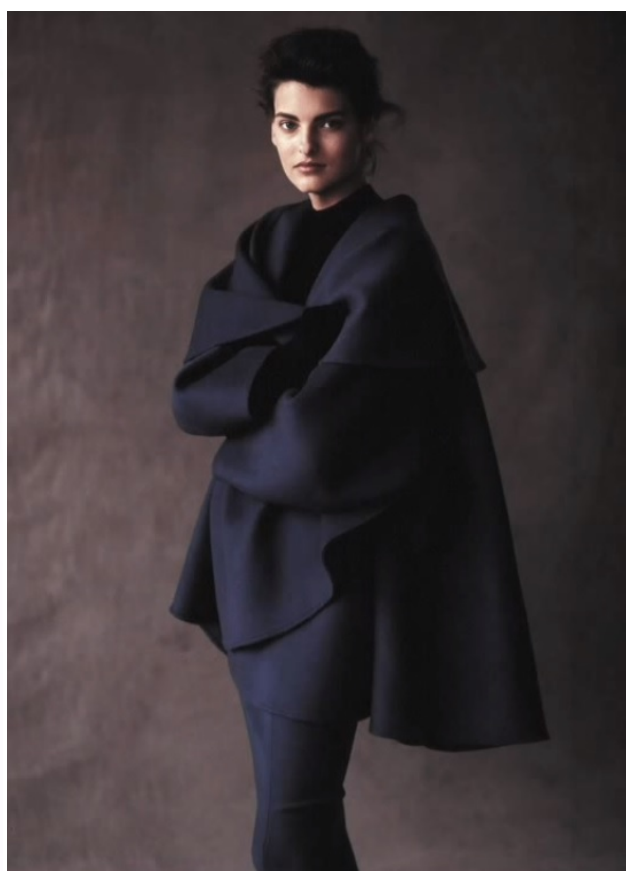

(b): A coat designed by Calvin Klein too relates to architecture.

Figure (1): Clothes inspired by architecture designed by Calvin Klein (Klein, 2015) 


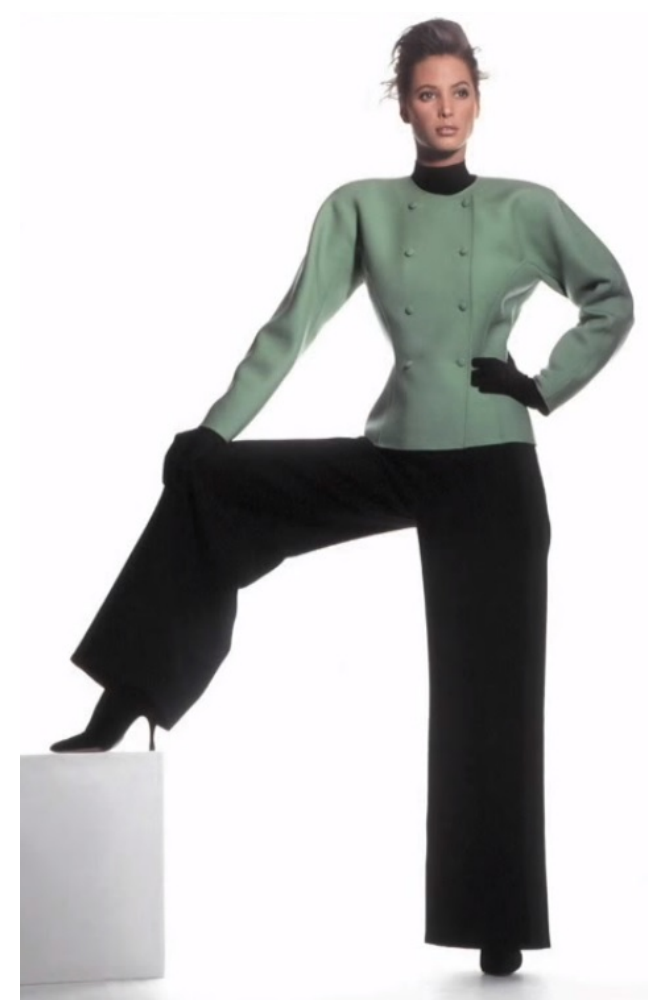

Figure (2): Fashion design relate to architecture designed by Calvin Klein

(Klein, 2015)

"In fashion world, we would say the shape of her shoulder, the shape of the arm hole, the sleeve, and the curve to the waist is architectural." (Klein, 2015) talking about Figure (2).

Thus, he confirmed Chanel's saying especially when he mentioned to Georgia O'Keeffe's courtyard in Santa Fe at abiquiu that:

".. to me, the architecture, the colors and the form said everything that I wanted to say about the work that I was doing at that moment." (Klein, 2015)

So, while fashion is called "second skin" because it surrounds the human body and protects it from external factors, and it also performs an aesthetic function, the architecture is named "third skin" because it provides the same protection and aesthetic role, but on a broader scope includes the human body and its personal space. (Quinn, 2003)

Given architecture and fashion are fundamentally based on art, the correlation of two worlds is often clear and continuous in many cases (Woods, 2009), especially when art provides both directions with the same concept as Mondrian's iconic painting, which is called "compositions" and it has been used in various projects through architecture and fashion (Figure 3-6) (Lafer, 2017). 


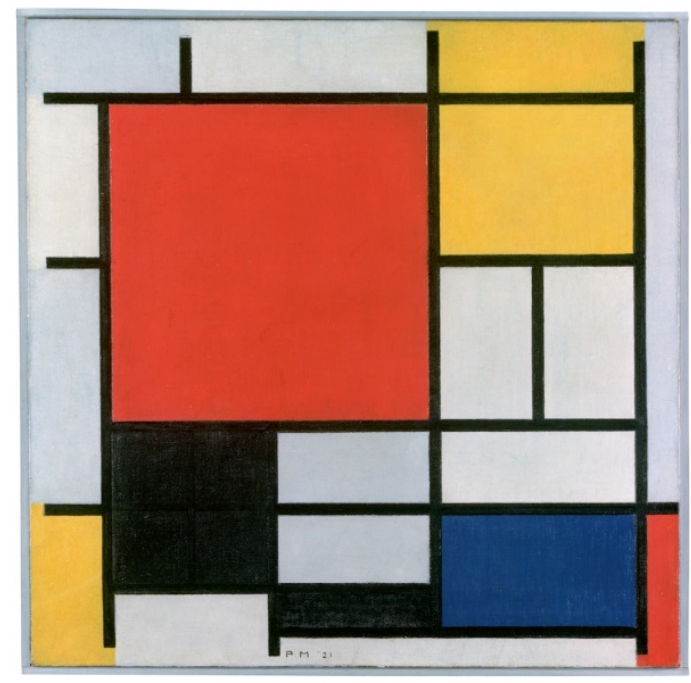

Figure (3): Mondrian, Composition with Large Red Plane, Yellow, Black, Gray and Blue (1921), courtesy of Gemeente Museum Den Haag (Lafer, 2017)

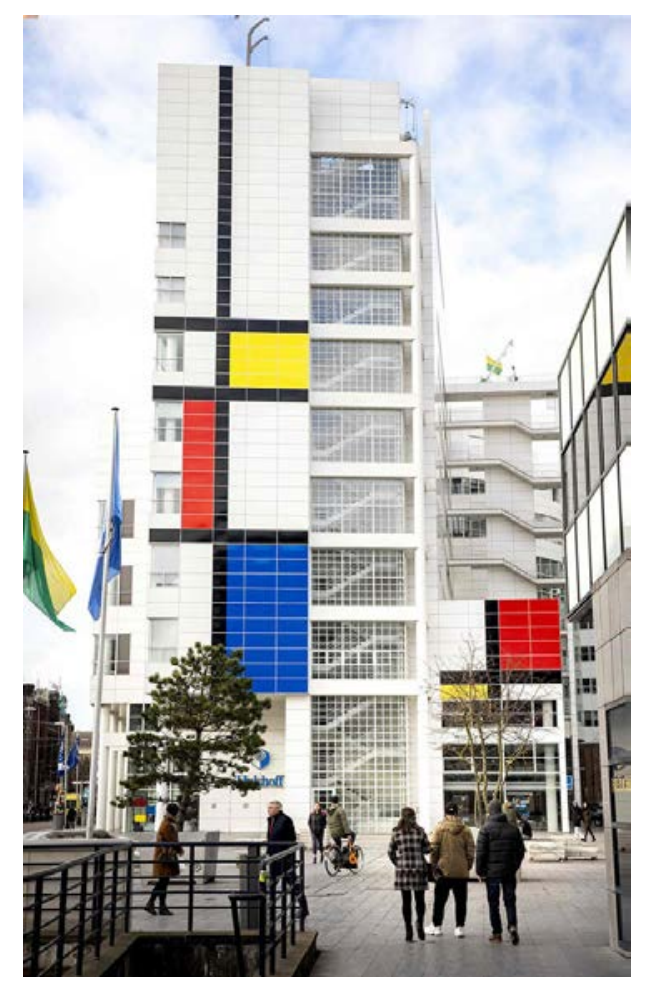

Figure (4): A Mondrian painting on the City Council of The Hague (Lampen, 2017) 


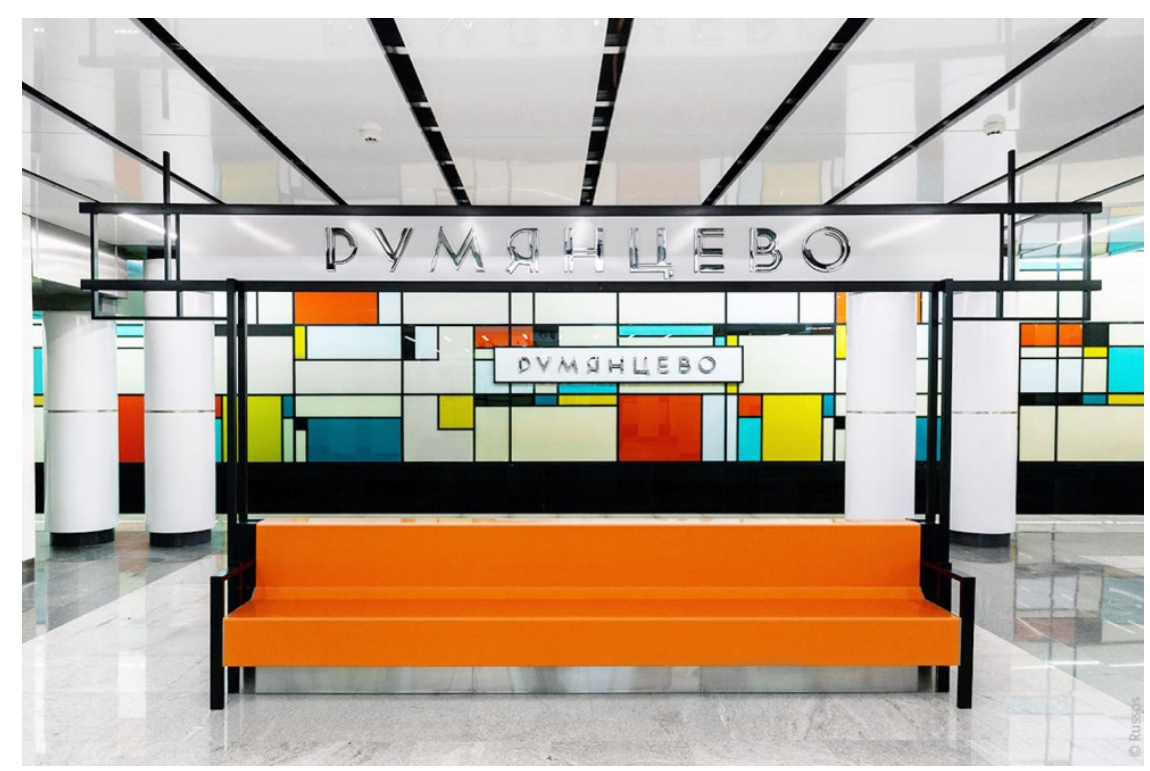

Figure (5): a Mondrian in interior of Rumyantsevo Station in Moscow, courtesy of Lebedev Studio (Lafer, 2017)

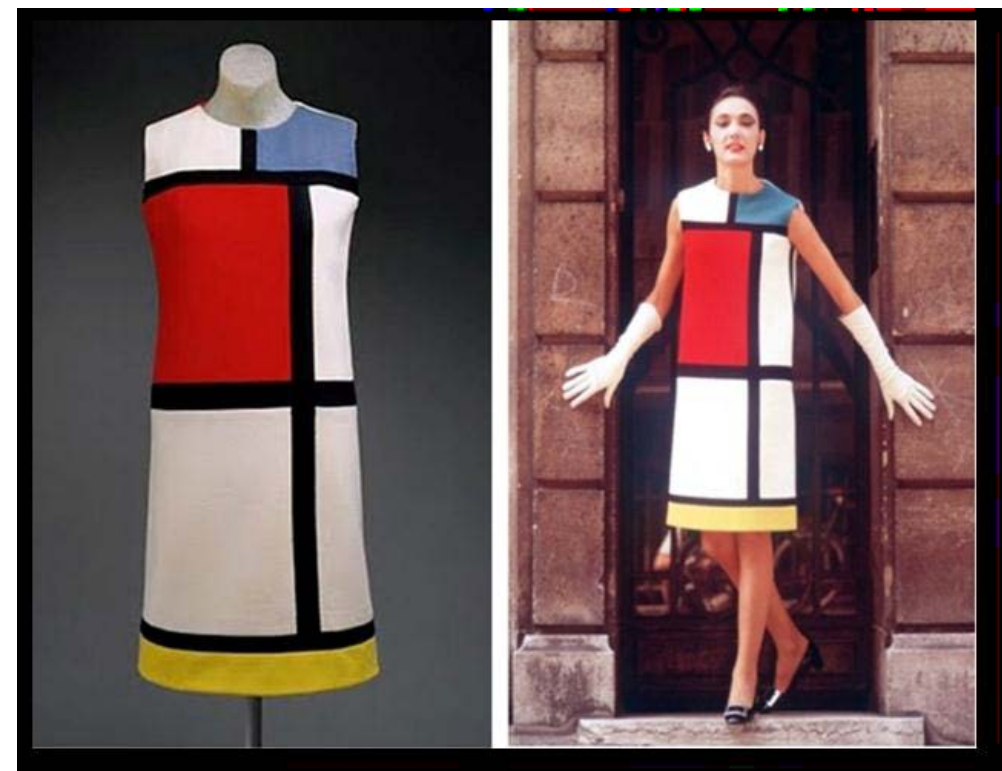

Figure (6): This iconic Yves Saint Laurent dress was inspired by Piet Mondrian. Presented in 1965 (Angus, 2012)

As mentioned before, architecture and fashion have also affected on each other, and the most important examples those had taken an inspiration from famous projects like fashion accessory hat style inspired by Guggenheim Museum that designed by Frank Lloyd Wright (Figure 7) (Chinwendu, 2014). 


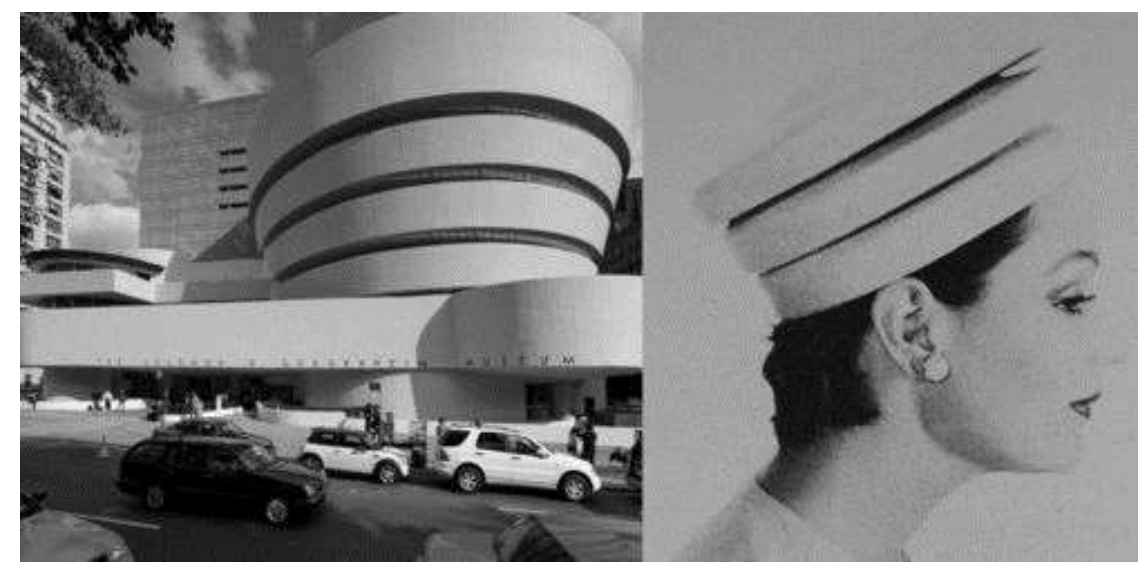

Figure (7): The Guggenheim Hat (Williems, 2011)

Many websites and researches documented that Guggenheim Museum was the muse for this hat, and unfortunately without mentioning to any information about the fashion designer name/thoughts, nor the date/year/country of design.

In distinctive cases, fashion has been based on the heritage of ancient peoples and their buildings, presenting fashion shows inspired by authentic architecture, such as Phillip Lim and Chloé designs whose admitted that they got a great inspiration by different heritage architecture like Islamic one where they evolved from creative director Clare Waight Keller's fascination with Islamic architecture, the infinite patterns that is very common in Middle East (Figure 8). (Janet Morais, 2016)

"In my Summer 2016 collection, I created a series of pieces made up of elements of exaggerated details from Arabesque architecture," she says, "working the proportions on a larger scale and piecing them together to create edges and straps and to frame dresses and tops." (Chloé Phillip, 2016)

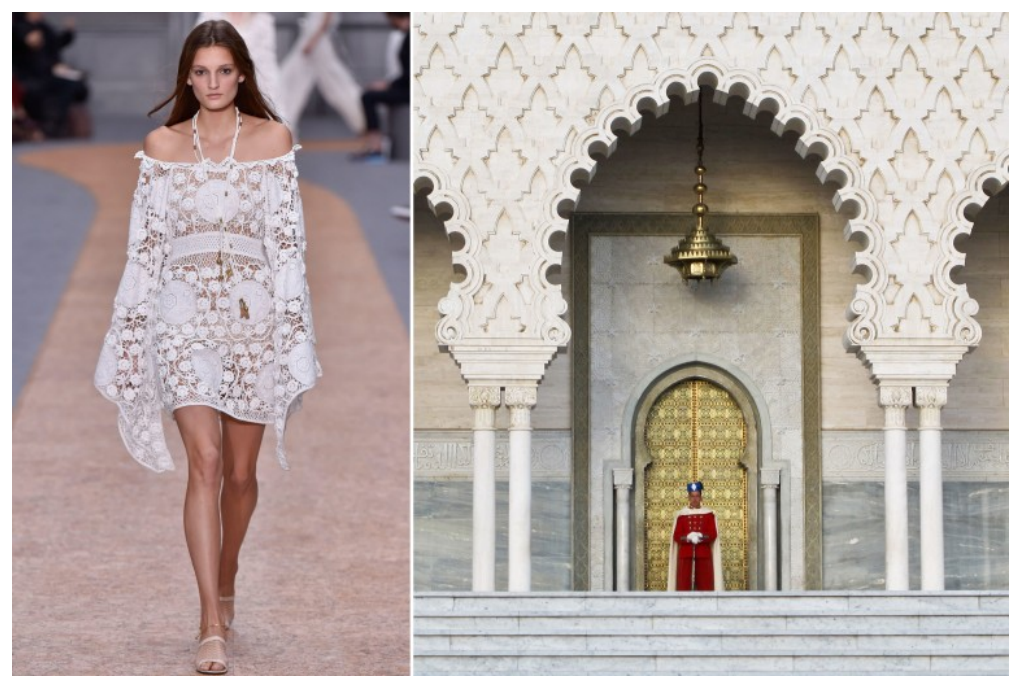

Figure (8): A dress designed by that is inspired by the Mausoleum of Mohammed V in Rabat, Morocco (Morais, 2016)

Like these designs are considered as a strong preface to introduce another Arab architectural element later that is as heritage and influential as Mashrabiya with its exquisite patterns to merge within the fashion movement. 
Contrariwise, through another famous example the architecture project was inspired by a fashion design, ThyssenKrupp building which designed by Zaha Hadid, she inspired it from the flowing mesh dress which she designed it before in her fashion playbook named frozen aura (Figure 9) (Chinwendu, 2014).
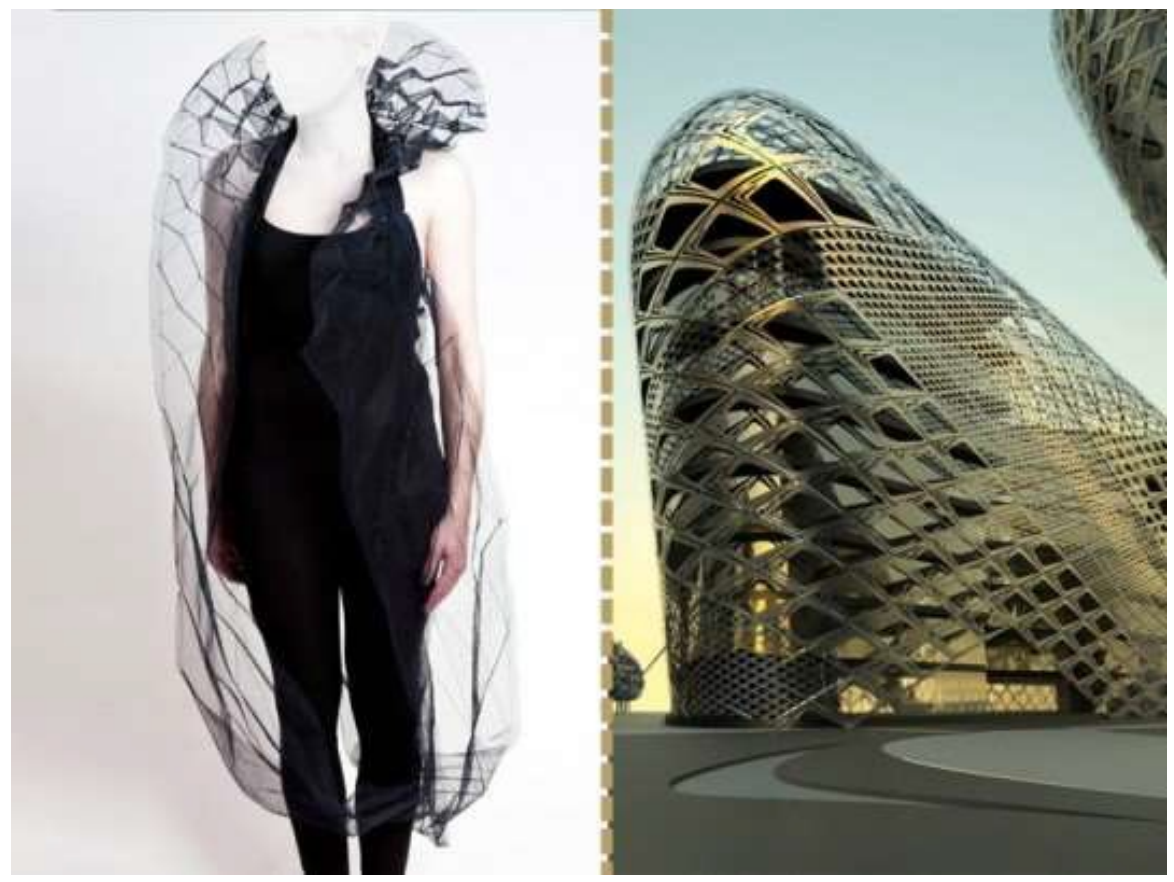

Figure (9): Zaha Hadid's building (ThyssenKrupp building) inspired by one of her fashion design.

(Sharonne, 2014)

As a result, architecture and fashion share common concepts from external sources (art, science, technology), and both of them affect on each other, additionally they are influenced by factors such as culture, society, time and environmental conditions.

And it worth to denote that while fashion designs under the impact of architecture were in general more technical, structurally and somehow complex, Mashrabiya has presented practical, active and more comfortable designs within fashion and jewelries field that can be used on a daily basis.

\section{MASHRABIYA IN FASHION: CASE STUDY}

\section{BACKGROUND OF MASHRABIYA}

Mashrabiya is the prominent window that overlooks the street or the courtyard of traditional Arab houses. The screens of window were made of wooden balusters and completely hand-made (Figure 10-11). The design of the balusters was varied in different artistic ways and according to it, there are many patterns of Mashrabiya that some of them have known names such as the hexagon, the church, the Maymoni, the Sahrigi and the cross pattern (Figure 12) (Alothman, 2017). Besides, many modern hybrid patterns (Figure 13). Here, it is worth to observe that the hexagon pattern (Figure 14) of Mashrabiya has been more common used in fashion field, while the hybrid patterns have become profitable within jewelries and accessories designs process (Akçay and Alothman, 2017). 


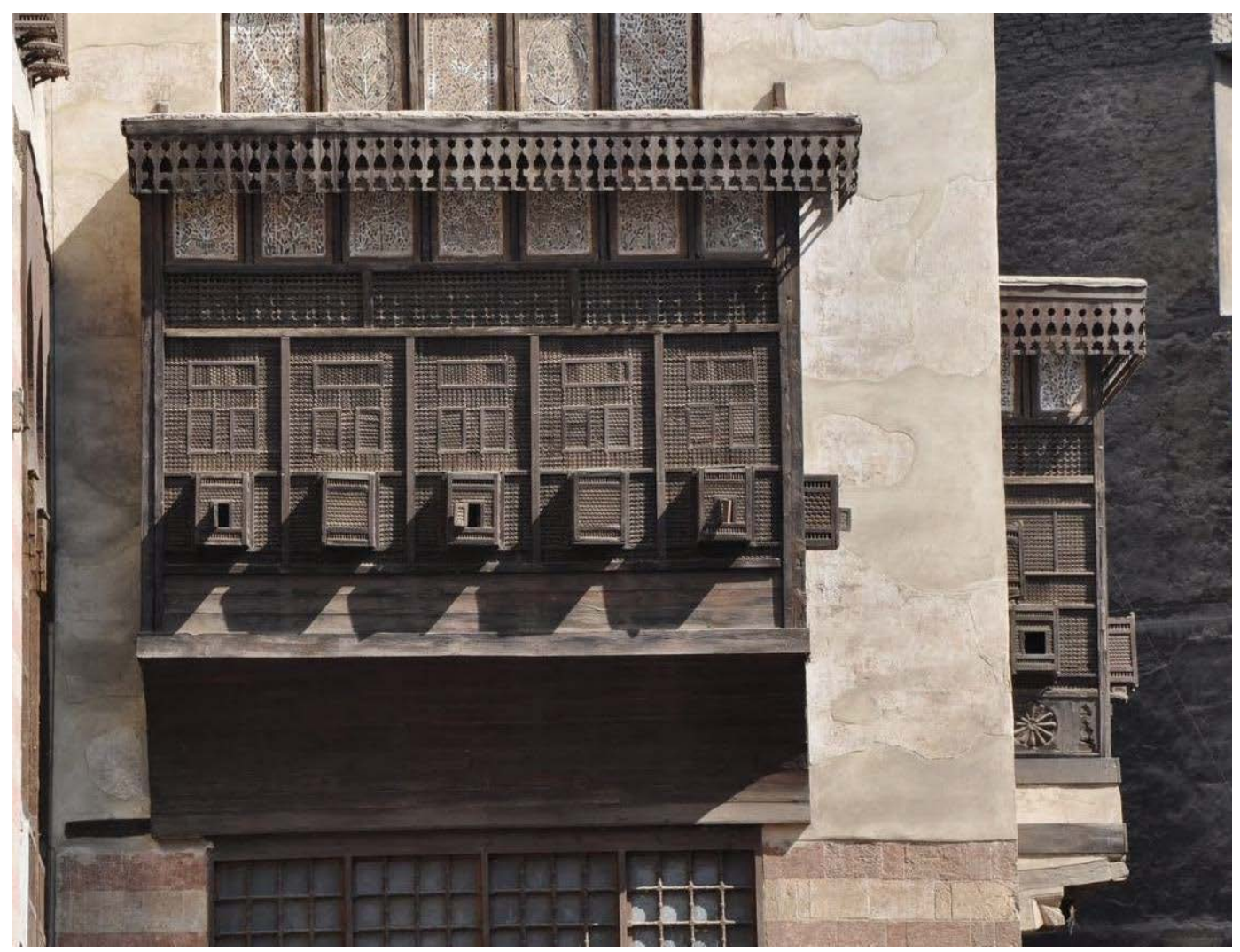

Figure (10): Mashrabiya at alSuhaiymi house in Cairo, Egypt (Valadi, 2015)

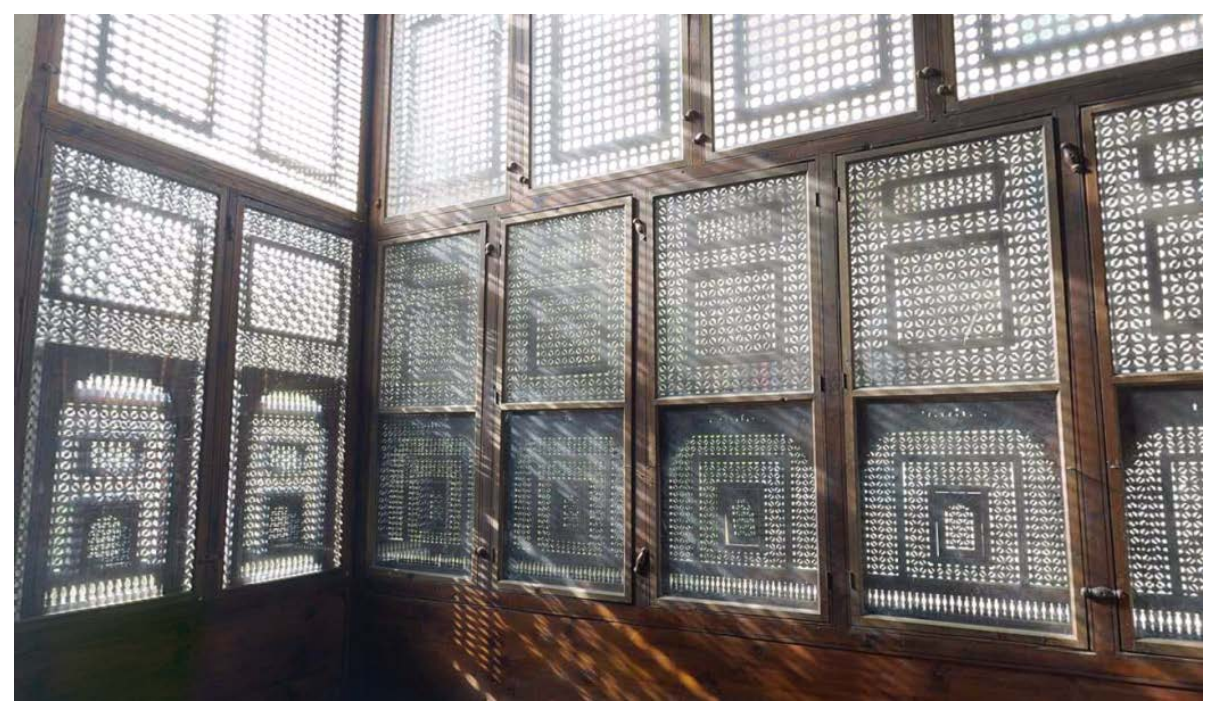

Figure (11): A beautiful interior with Mashrabiya at Al Suhaymi House in Cairo, Egypt (Alothman, 2017) 


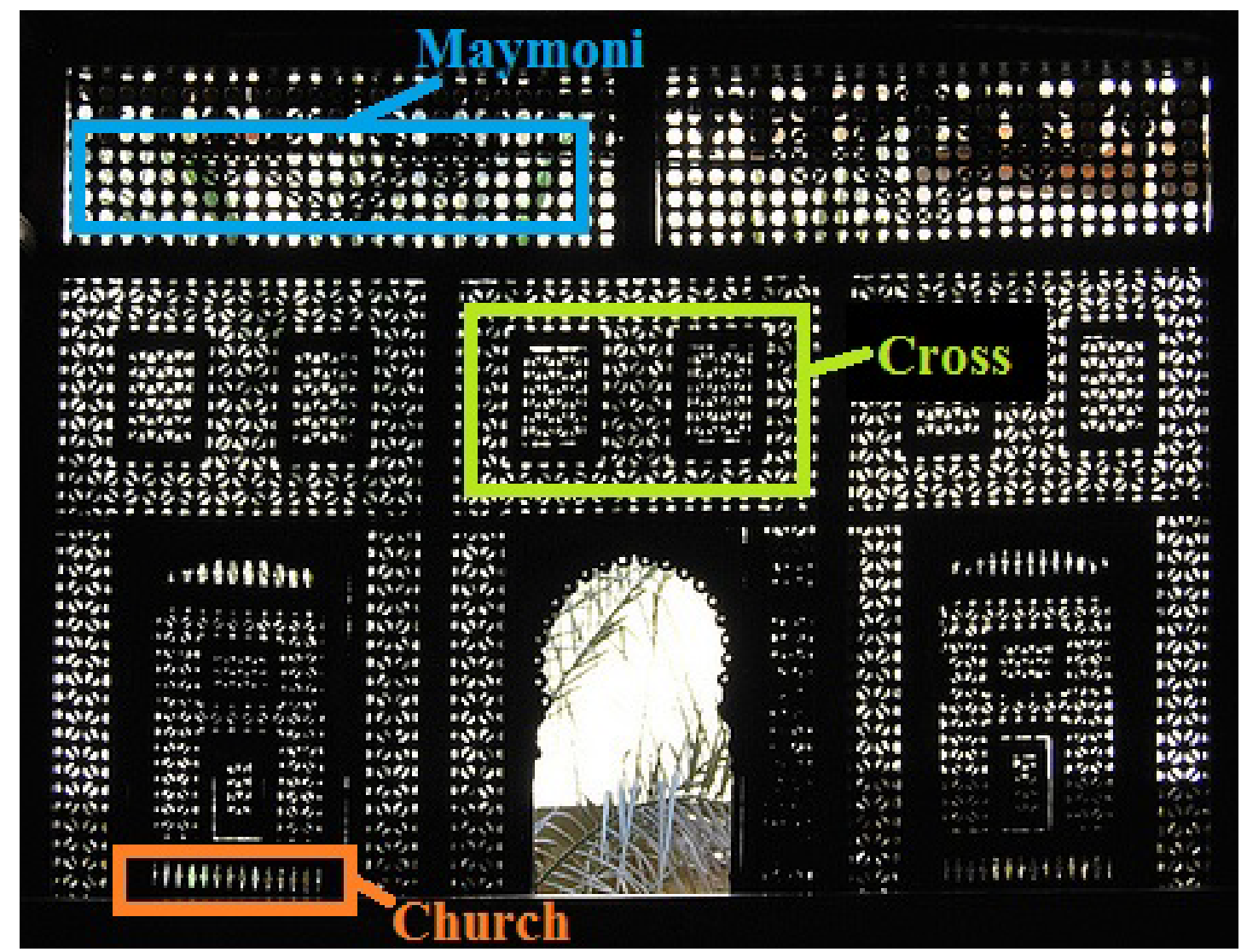

Figure (12): An interior view of Mashrabiya contains different patterns at al-Suhaymi House in Cairo, Egypt (Alothman, 2017)
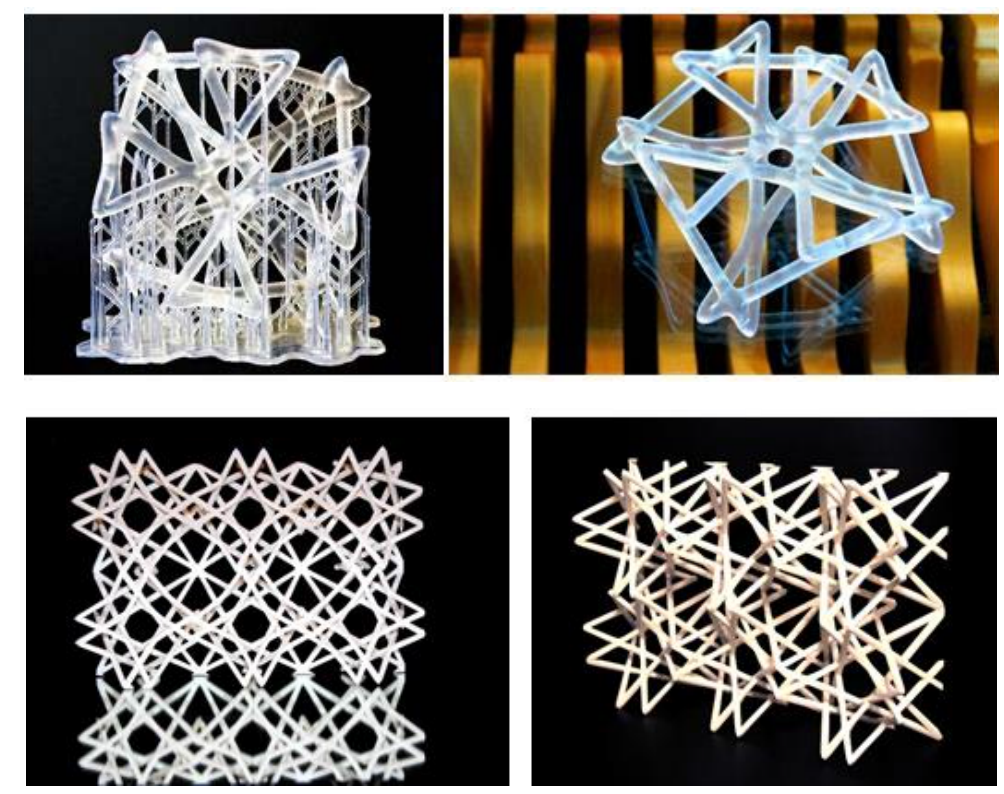

Figure (13): Different hybrid patterns of modern Mashrabiya (Almerbati et al., 2016) 

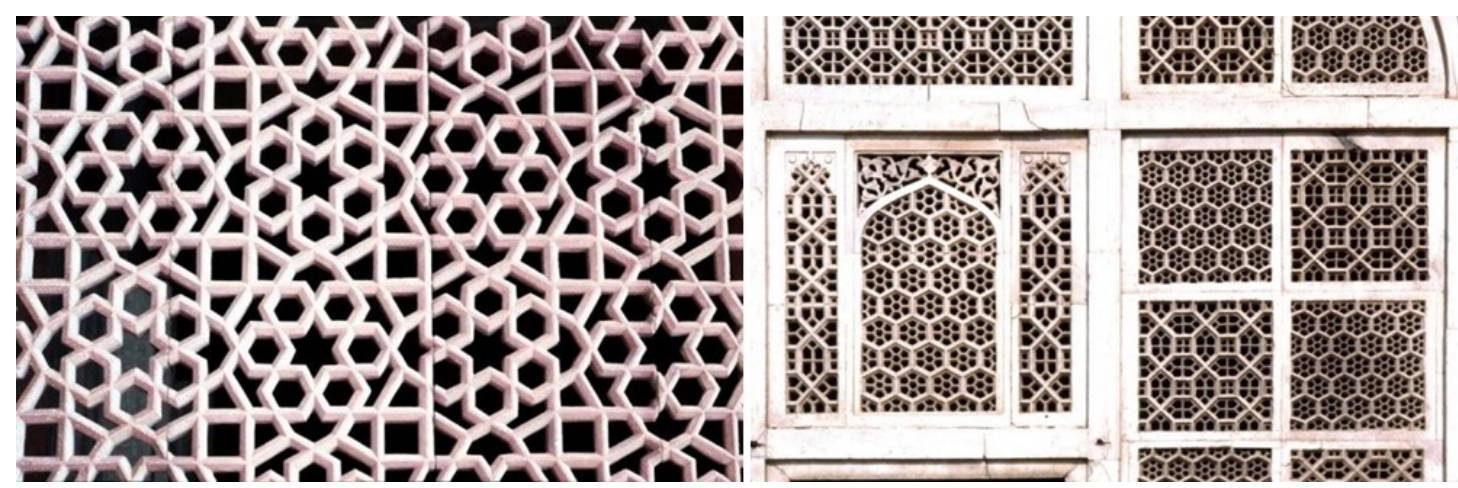

Figure (14): An image showing details of the hexagon pattern of Mashrabiya

(Pattern in Islamic Art, 2016)

The Mashrabiya has an inherent history, but this does not mean that it is just a culturally decorative element. It has also many important functions that helped to find solutions to contemporary variables and become a significant environmental element with design criteria and determined parameters of its own (Figure 15) (Akçay and Alothman, 2017).

Flat window (qamariyyah) for increasing lighting and airflow

Overhang for breaking sunrays

Upper section with a wide lattice for lighting and ventilation

Lower section with a tight lattice

for insuring privacy and intercepting sunlight at eye level
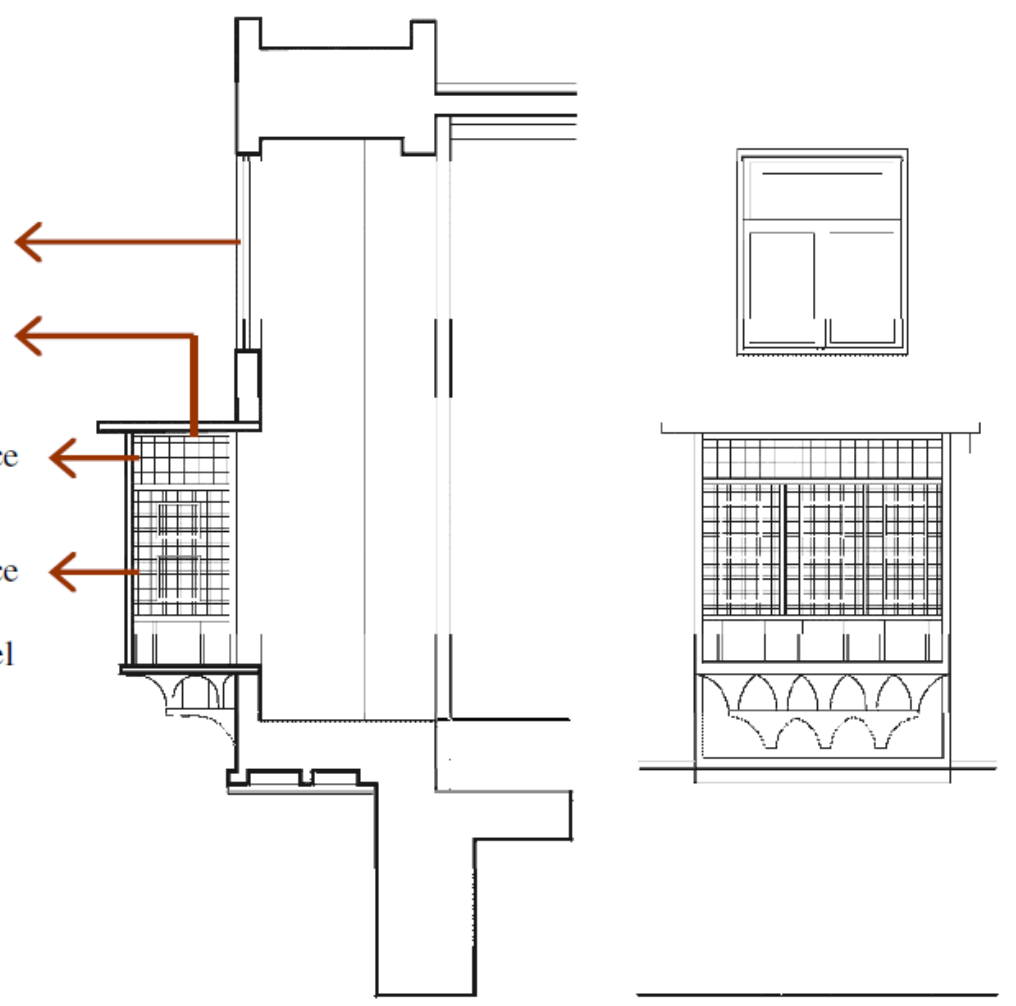

Figure (15): A typical Mashrabiya in the Northern qa'a of Zaynab Khatun House

(Gelil and Ali, 2014)

Fathy asserted (in 1986) that Mashrabiya has, in general, five functions, and many models of these have been developed to describe ways of coping with the different conditions affecting one or more of these functions. The main functions are: 
1- Light Control. 2-Airflow Regulation. 3- Humidity Control. 4- Temperature Regulation. 5- Visual Privacy. In addition, there are also the aesthetic, social and spatiality properties of the Mashrabiya which cannot be overlooked.

Talking about the aesthetic role of Mashrabiya, the different patterns of it imbued life and vibrancy to the façades of traditional buildings which were previously extremely bare and gave a solid and harsh impression due to the heavy walls. Additionally, it should not be ignored that the Mashrabiya is an important expression of Eastern identity (Figure 16) (Alothman, 2017).

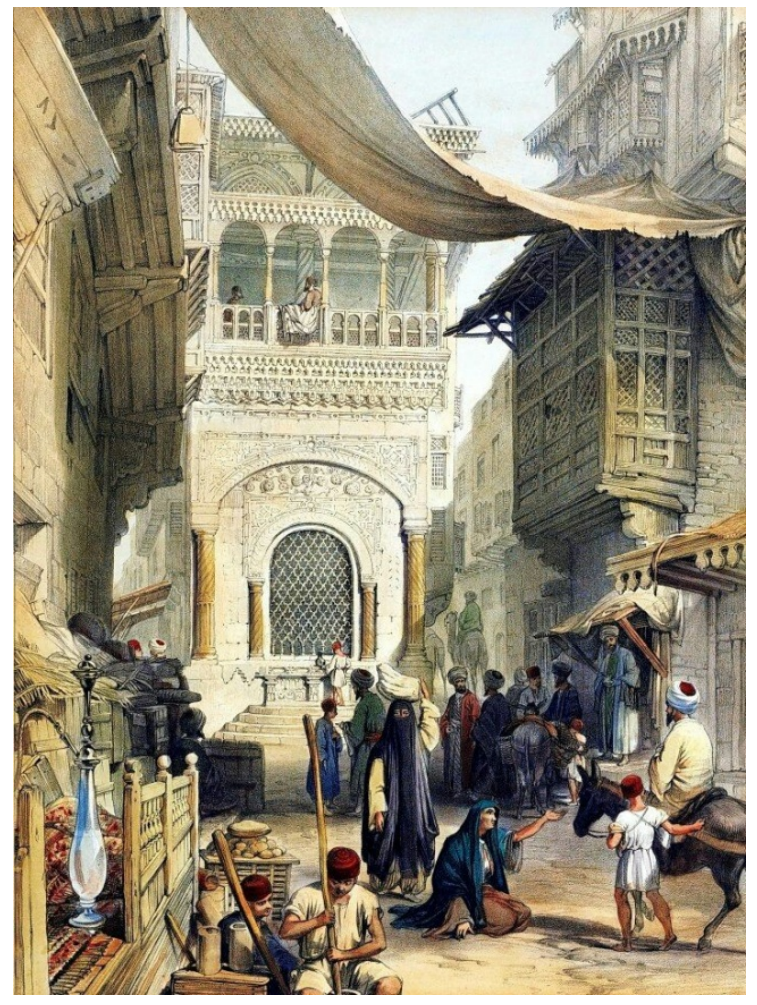

Figure (16): A Painting titled "Streets of Cairo" by the architect Owen Browne Carter, which shows the Mashrabiya in 1800's (Hay, 1863)

\section{MASHRABIYA IN ARAB FASHION AND JEWELRIES DESIGN}

The culture and architecture are linked closely, due to that culture equips the world view of society and people perceptions. Hence, the culture effects on the architectural environment, in addition it has an obvious influence on fashion. And this effect is reciprocal.

"Culture is the way of understanding the relationship that human of one society has with its built environment" (Fernando, 2008).

"Among other things, both language and cloths may serve as indicators and codes of cultural processes, but they are essentially involved in their creation as well, making it easier to determine one's own identity. Culture is generated through communication and is thus subject to a process of constant change" (Loschek, 2009).

Thus, architects and fashion designers seek always to involve the concepts and symbols that are related to cultures and history in their designs to get the acceptance of society. At this point speaking about Mashrabiya, the modern Mashrabiya has been revival in many contemporary projects thanks to its powerful environmental functions. such as Mashrabiya Towers in UAE, Doha Tower in Qatar and Arab World Institute 
in France. But through the fashion, the aesthetic role has been the main one. The beautiful patterns of Mashrabiya have given the uniqueness to fashion designs, and within an interrelationship the fashion trend has shed light on the original identity of this heritage element. On the runway, some rising Arab designers have chosen to introduce Mashrabiya as a concept for their designs, but this approach is still considered as a new idea, so the number of designers who have adopted the concept is limited. And the Qatari designer Wadha Al Hajri is the most famous name so far. She has designed a number of collections named Mashrabiya (Figures 17-20) (Hamilton, 2014).

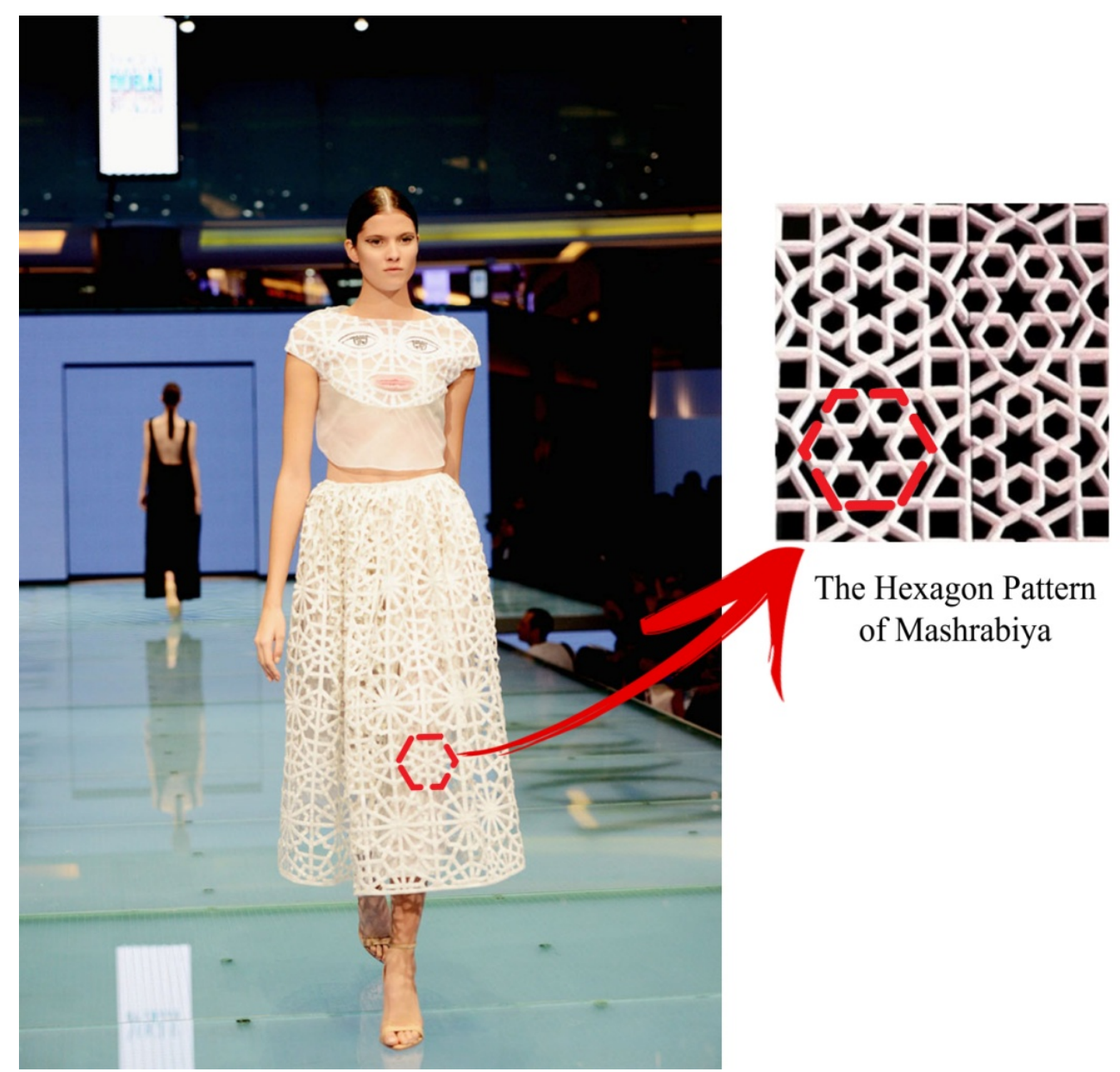

Figure (17): Mashrabiya dress designed by Wadha Al Hajri in the Vogue Fashion Dubai Experience at Dubai Mall (Tang, 2013) (Illustration by author Alothman) 


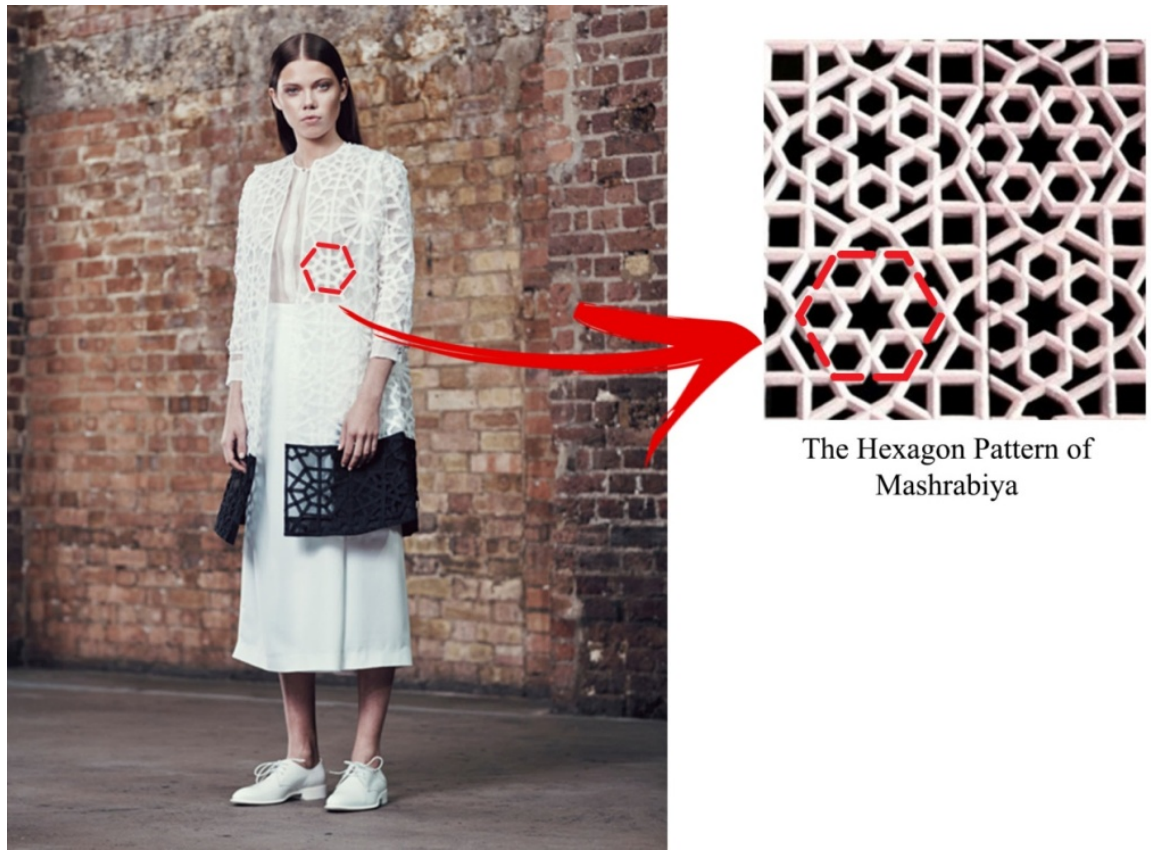

Figure (18): Mashrabiya coat from Spring / Summer 2015 collection designed by Wadha Al Hajri (Al Hajri, 2015) (Illustration by author Alothman)

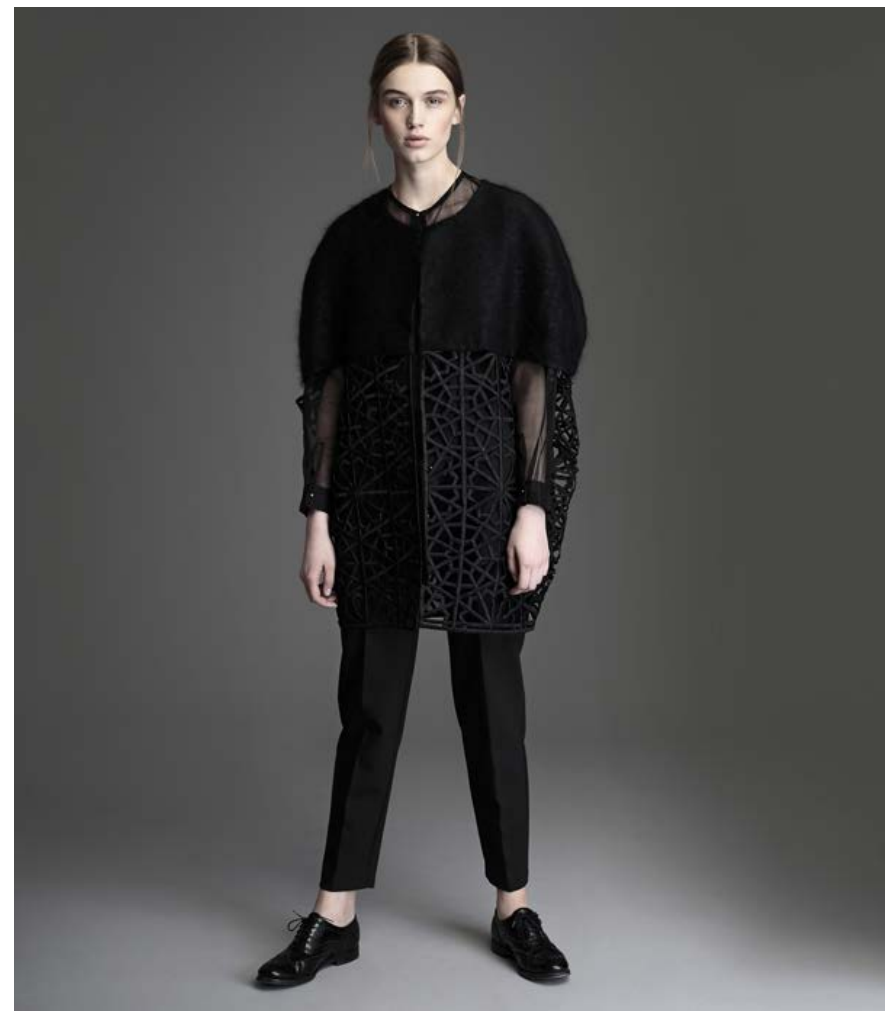

Figure (19): Mashrabiya coat from Autumn / Winter 2014 collection designed by Wadha Al Hajri (Al Hajri, 2014) 


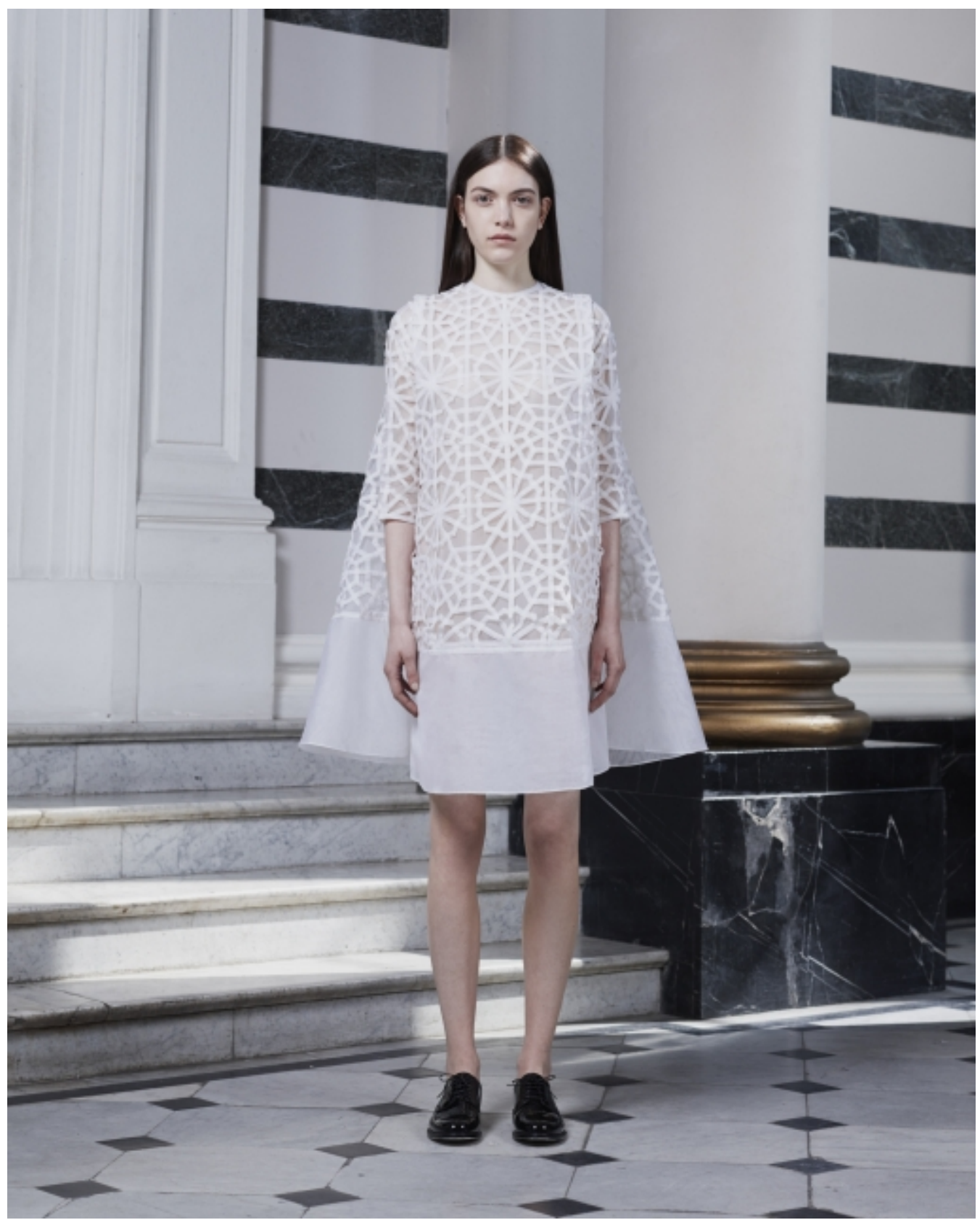

Figure (20): Mashrabiya dress from Autumn / Winter 2015 collection designed by Wadha Al Hajri (Trevis, 2015)

"It is important to incorporate my background and heritage into the designs as a source of inspiration, while using modern cuts and new sources of fabric to display harmony between the past and the future," Alhajri said (Trevis, 2015)

While the Jordanian designer Anas Younis Shanaah comes in with his new shoes and bags label titled aennis eunis. And he picked out the Arabic calligraphy on his productions, he also tried to use the pattern of Mashrabiya on some designs of shoes (Figure 21) (Confashions, 2011). 


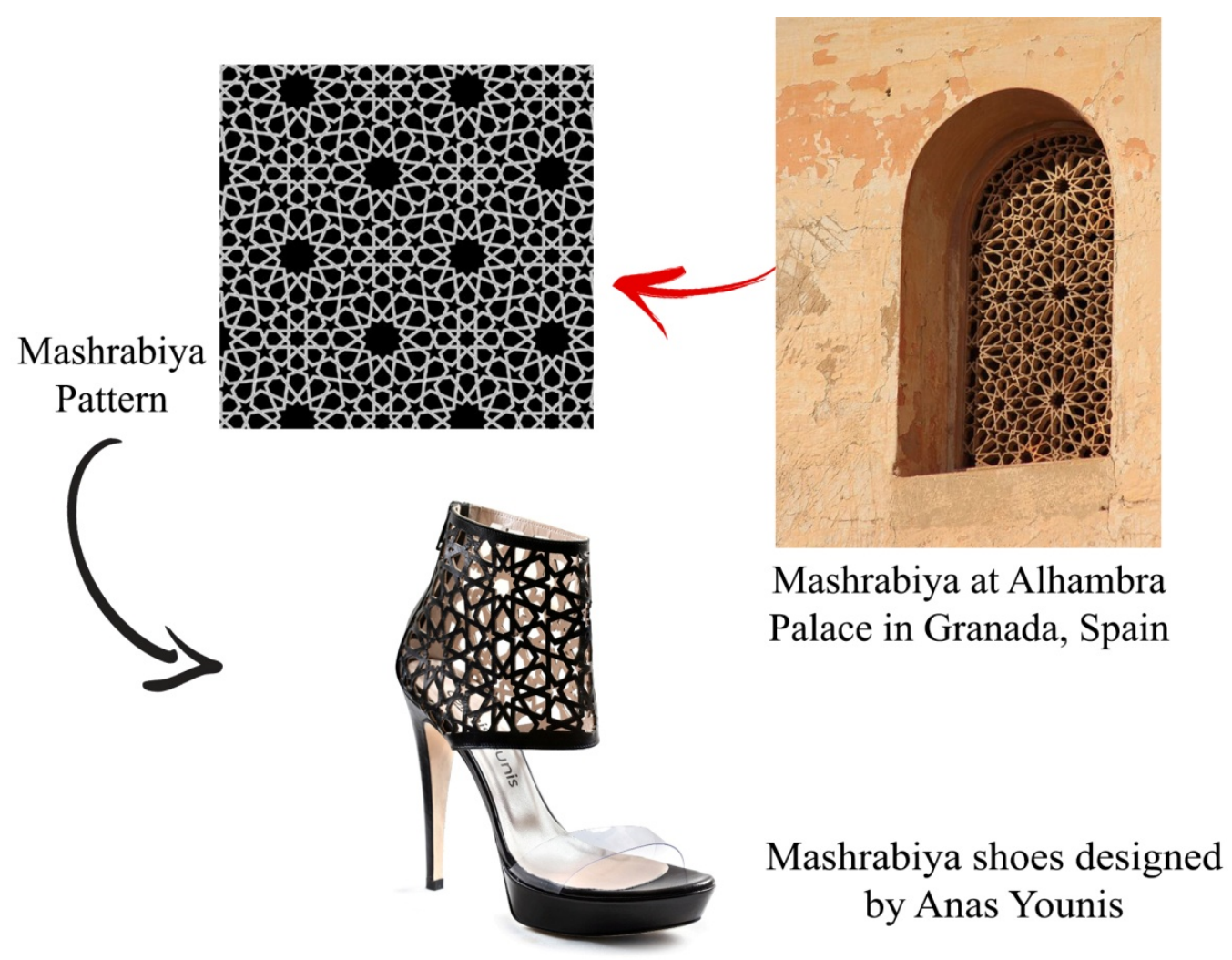

Figure (21): Mashrabiya shoes designed by Anas Younis

(Source: Shoes; Confashion, 2011 Mashrabiya at Alhambra Palace photo; Poole, 2009) (Illustration by author Alothman)

While a few foreign designers working in jewelry design companies in the Middle East and the Arabian Gulf in particular have been influenced by the idea of integrating Mashrabiya with jewelry to present a new product that is highly popular based on the concept of local identity expressed in Mashrabiya

These attempts have not spread far outside the Arab region, but they have been worthy of being highlighted to encourage continuity and presenting greater diversity of designs.

With regard to jewelry designers names, Mario Uboldi Jewellery Art is considered the most recognized company which is a trademark dates back to the state of Milan, Italy, registered in Switzerland and located in Dubai, UAE. The designer's approach of company focuses on analyzing phenomena in art, culture, nature and architecture and distills them to their core parameters to get at their underlying principles. By combining diverse attributes, such as historic and contemporary characteristics, a new visual dialogue emerges which is rooted in its references. André $C$. Meyerhans, the founder and designer of Mario Uboldi Jewellery Art, is an architect, and he has been named one of the twenty-five most influential architects in the MENA region by Middle Eastern Architect magazine in 2015, 2016 and 2017. (https://www.mariouboldi.com/pages/about-us)

The company has chosen recently to offer light unique and youth jewelry based on patterns of Mashrabiya (Figures 22-24) ( https://www.mariouboldi.com/ ) 


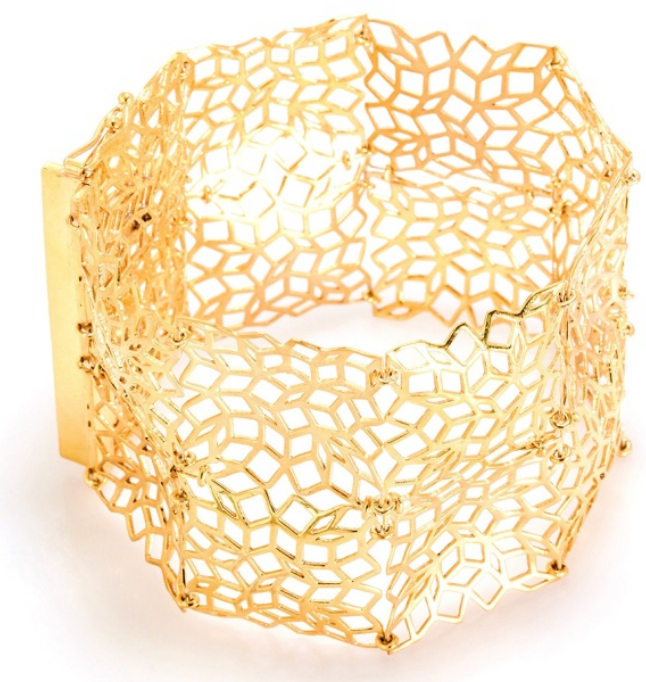

Mashrabiya Bracelet, Produced by Mario Uboldi Jewellery Art

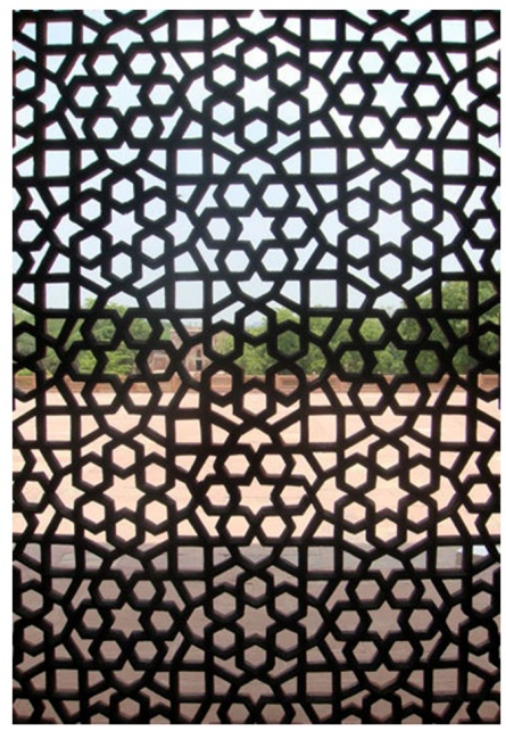

Mashrabiya Screen at Taj

Mahal and Agra Fort, India

Figure (22): Mashrabiya Bracelet, Produced by Mario Uboldi Jewellery Art (2016) (Sources: Bracelet: Mario Uboldi Company, 2016 - Mashrabiya Screen: Coffey, 2009)

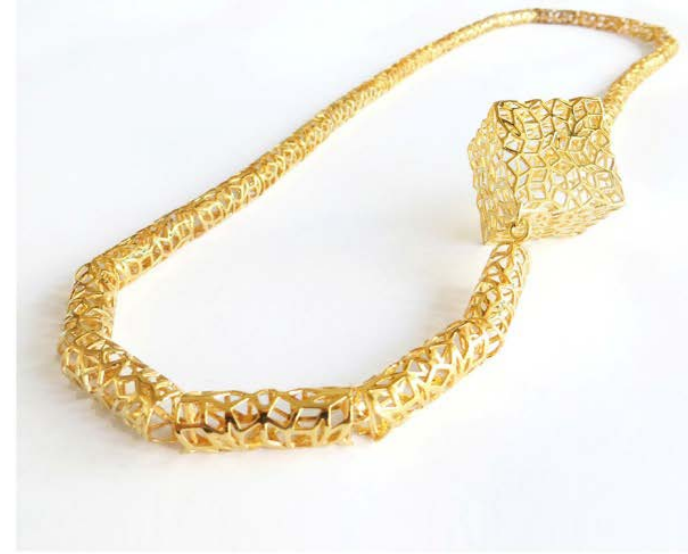

Mashrabiya Collier, Produced by Mario Uboldi Jewellery Art

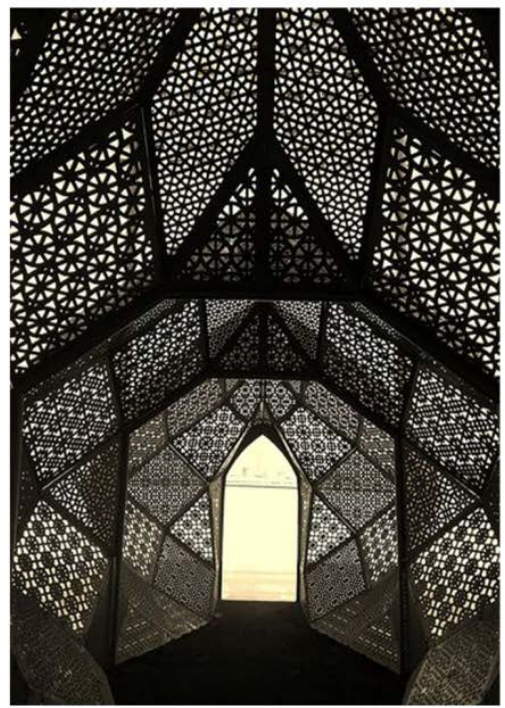

Mashrabiya Screens at Bahrain National Theatre

Figure (23): Mashrabiya Collier, Produced by Mario Uboldi Company (Sources: Mashrabiya Collier: Mario Uboldi Company, 2016- Mashrabiya Screens at Bahrain National Theatre: BenGiuma, 2013) 


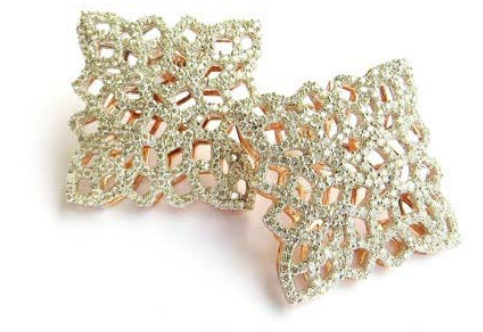

Mashrabiya Earrings, Produced by Mario Uboldi Jewellery Art

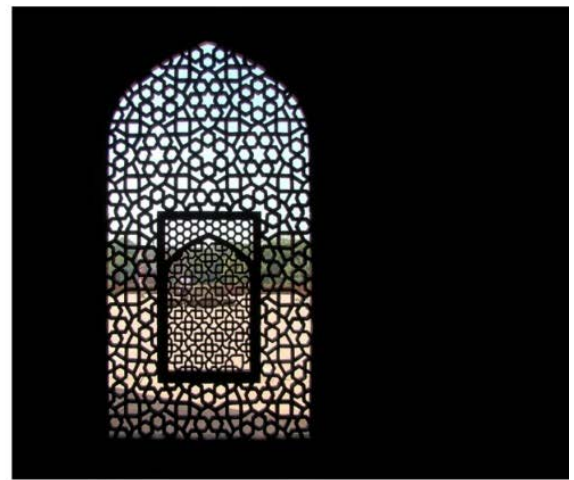

Mashrabiya at Humayun's tomb, india

Figure (24): Mashrabiya Earrings, Produced by Mario Uboldi Jewellery Art (2016) (Source: Earrings: Mario Uboldi Company, 2016, Mashrabiya Screen: Bhagwati, 2010)

While some Mashrabiya jewelry were designed to be practical and for daily using, other designs introduced Mashrabiya concept through forms that associated with symbolism and strangeness sometimes. Such as Mashrabiya Mask which is designed by André C. Meyerhans via Mario Uboldi company as well, the mask could be a reminiscent of a famous photograph entitled (Woman Behind Mashrabiya, 1997) by Susan Hefuna a German/Egyptian (Figure 25).

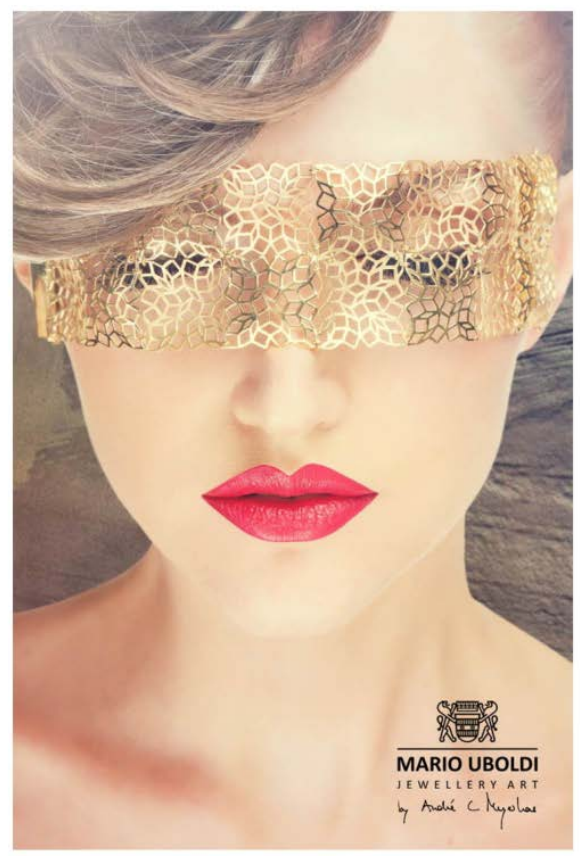

Mashrabiya Mask designed by André C. Meyerhans via Mario Uboldi company

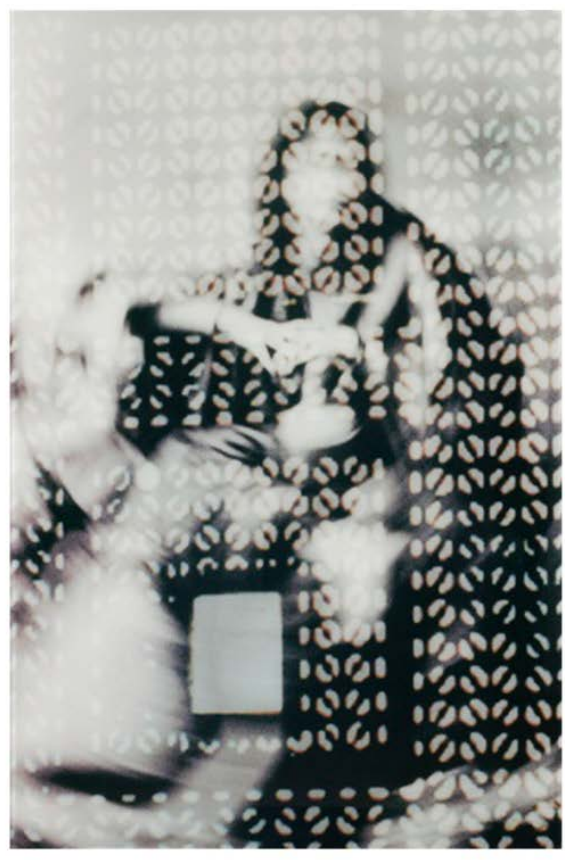

Woman Behind Mashrabiya, (1997) photograph by Susan Hefuna

Figure (25): Mashrabiya Collection, Mask designed by André C. Meyerhans via Mario Uboldi company (Source: Mask: Meyerhans, 2016, Women Behind Mashrabiya: Hefuna, 1997) 
The design and the indicative feeling show the privacy factor that has characterized the Mashrabiya through different times and made it achieved a great popularity around many Eastern countries.

Besides to André C. Meyerhans, there is another talent foreign designer in jewelries designs field, she is Astha Jagwani, and her most notable design is Mashrabiya ring by wrapping the empty space in a convex pattern of Mashrabiya is reminiscent of the spatiality factor characteristic of the traditional Mashrabiya where it secured a prominent space overlooking outside to be as a seat for the ladies, or to put a jar of water to get cool (Figure 26).

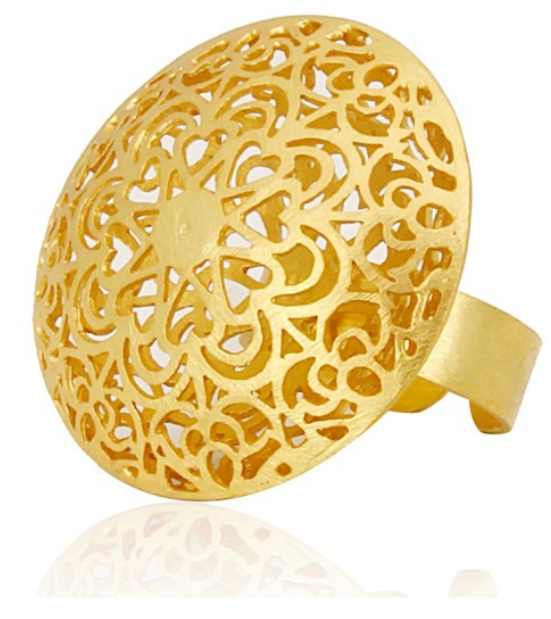

Gold finish Mashrabiya ring, Produced by Astha Jagwani
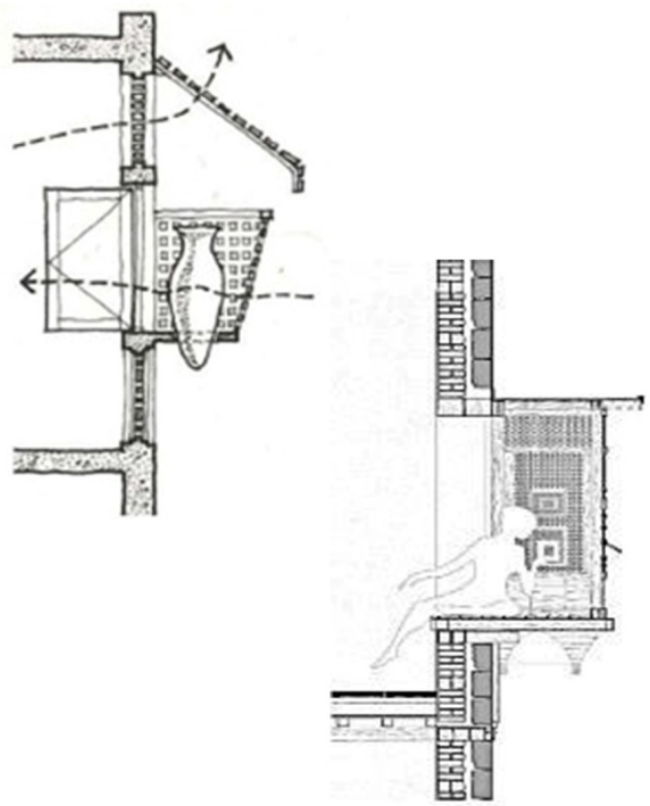

Spatiality factor of the traditional Mashrabiya as a seat or for water jars

Figure (26): Gold finish Mashrabiya ring, Produced by Astha Jagwani

(Source: Mashrabiya Ring: Jagwani, 2016, Mashrabiya Screen Illustration: Ficarelli, 2008)

As for the Ukrainian Bob Basset designer who presents a creative leather art handicraft, has chosen the name of Mashrabiya for one of his collections that took on an oddity touch through using of overlapping layers of Mashrabiya, and as a result he presented a solid model of Mashrabiya (Figures 27-28) (http://bobbasset.com/items/mashrabiya-black-art-leather-mask). 


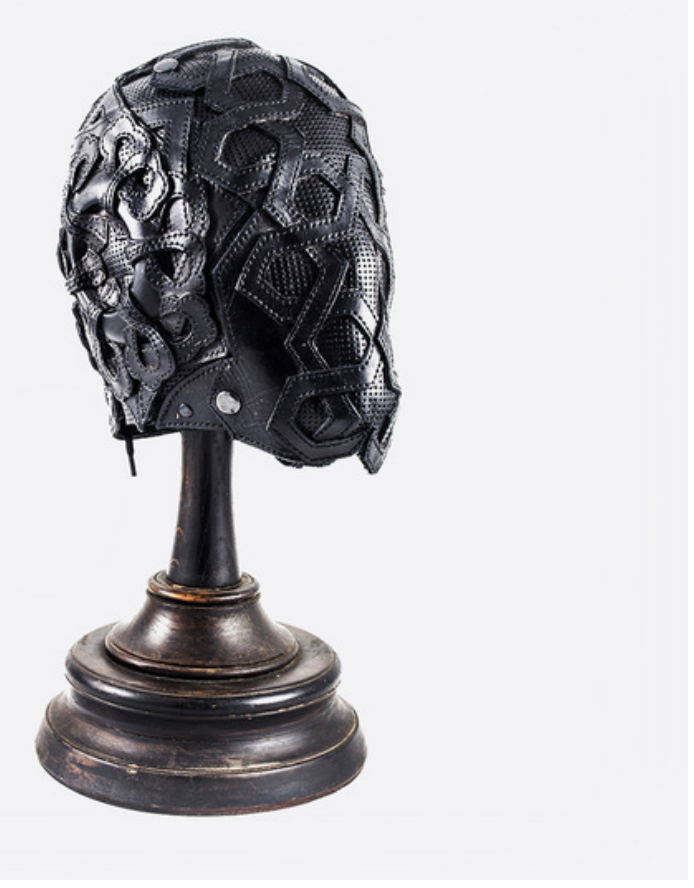

Figure (27): Mashrabiya Black Art Leather mask designed by Bob Basset (2015)

(Basset, 2015)

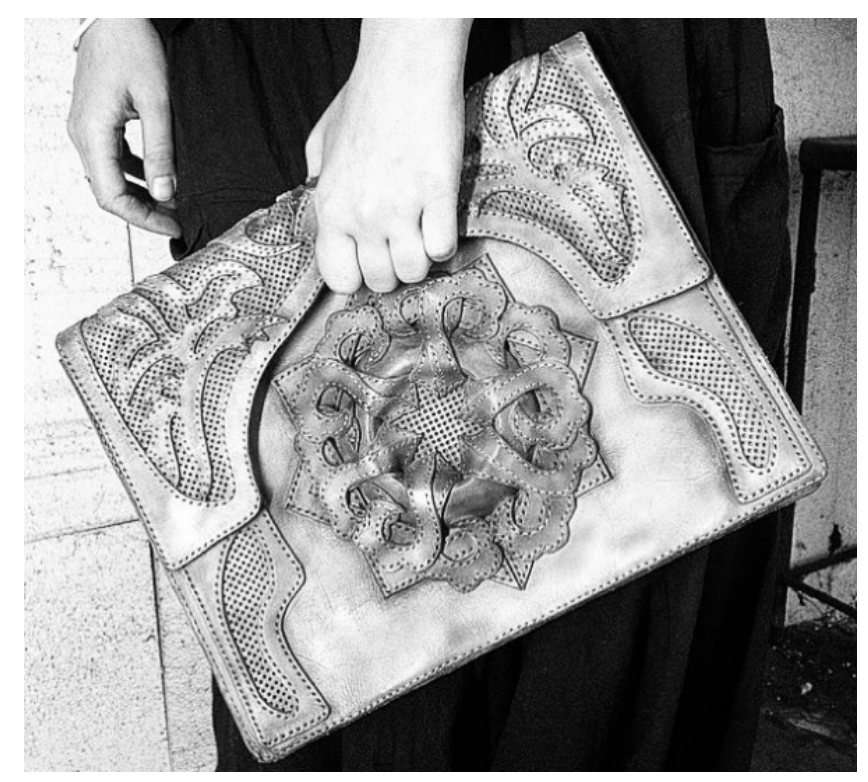

Figure (28): Mashrabiya leather bag designed by Bob Basset

(Basset, 2015)

"The collection of leather masks called "Mashrabiya" is a mixture of geometric lines and floral applique, combined with sophisticated handmade" (Basset, 2015).

Thus, although designs related to Mashrabiya within fashion and jewelry are still limited, they have given deep meanings and provided aesthetic details that are very charming. Subsequently this approach makes people who are interested in the fashion world are also connected to the world of architecture and familiar with an important architectural element such as Mashrabiya. 


\section{CONCLUSION: THE CONTINUITY LIMITS}

Architecture and fashion worlds, whether they are parallel, interdependent or based on a reciprocal relationship, they are originally founded for the human comfort and beauty depending on the dimensions of his body, therefore they must evoke his identity and personality. So, the integration of fashion and architecture is an exciting way to express identity through contemporary ways and it is a unique movement in the revival of heritage. As for the Mashrabiya, it is not denied to highlight on this authentic Arab element by fashion, but in such cases, however, the Mashrabiya should not be stripped of its vital functions as an architectural element and presented solely as an aesthetic element.

At this point it is worth mentioning the costumes that adopted the parametric architecture and made amazing performances without canceling the fact that the parametric is a direction of architectural engineering that is based on science and studied mathematical calculations.

So it is nice to combine Mashrabiya with fashion to provide creative designs that express identity without exaggerating to the point of misuse of the concept.

As the parametric dynamics and the fashion movement were also combined to provide parametric fashion, and the parametric surfaces didn't turn into merely aesthetic elements, the Mashrabiya should also be treated in the same methodology.

\section{REFERENCES}

Akçay, A. Ö. \& Alothman, H. (2017). A Theoretical Framework for the Evaluation from the Traditional Mashrabiya to Modern Mashrabiya. Journal of History Culture and Art Research 6(3), 107- 121.

Afzal, F. (2013). Architectural inspirations in fashion design. Retrieved September 15, 2017 from https://www.slideshare.net/franqi/architecture-fashion

Al Hajri, W. (2014). Mashrabiya Collection: Autumn/ Winter 2014. Retrieved April 28, 2016 from http://www.wadha.co/collection/86/Autumn-/-Winter-2014

Al Hajri, W. (2015). Mashrabiya Collection: Spring/ Summer 2015. Retrieved April 28, 2016 from http://www.wadha.co/collection/85/Spring-/-Summer-2015

Almerbati, N.; Headley, D.; Ford, P. \& Taki, A. (2016). From Manual to Hybrid. Parametric Mashrabiya Digital Workflow for the Re-envisioning and Conservation of Eastern Architectural Screens and the Engagement of Digital Tectonics. The International Journal of Architectonic, Spatial, and Environmental Design, 10(2) 2937.

Alothman, H. (2017). An Evaluative and Critical Study of Mashrabiya in Contemporary Architecture. Master Thesis, Near East University, North Cyprus.

Angus, M. (2012). Mondrian Inspired. Retrieved June 24, 2012, from http://postandgrant.com/2012/03/13/mondrian-inspired/ 
Barzandeh, M. (2010). Fashion, Architecture and The Urban Environment: The Parallel Relationships Between Fashion and Architecture. Master Thesis, Unitec New Zealand University. New Zealand.

Basset, B. (2015). Mashrabiya Black Art Leather mask. Retrieved April 30, 2016 from http://bobbasset.com/items/mashrabiya-black-art-leather-mask; https://www.instagram.com/p/80WbzWtObO/

BenGiuma, A. (2013). Mashrabiya Screens at Bahrain National Theatre. Retrieved September 14, 2017 from https://www.flickr.com/photos/thehumanette/8569220073/

Bhagwati, S. (2010). Mashrabiya Screen at Humayun's Tomb, India. Retrieved September 14, 2017 from http://matralab.hexagram.ca/projects/jaali/

Black, E. (2016). Art is Architecture: The Designers of Project Runway Trunk Show. Retrieved July 01, 2017 from http://www.palmspringslife.com/art-is-architecture-the-designers-of-project-runway-trunk-show/

Chinwendu, A. (2014). Architecture + Fashion: A study of the connection between both worlds. Master Thesis, Nottingham Trent University, United Kingdom.

Chloé, Ph. (2016). 8 Fashion Designers that are inspired by architecture. Retrieved October 1, 2017 from https://www.lovehappensmag.com/blog/fashion-designers-inspiration-architecture/

Coffey, S. (2009). Mashrabiya Screen at Taj Mahal. Retrieved September 15, 2017 from https://www.apartmenttherapy.com/roundup-indian-screens-93407

Confashion, (2011). Introducing aennis eunis. Retrieved April 28, 2016 from http://www.confashionsfromkuwait.com/2011/02/introducing-aennis-eunis.html

Craven, J. (2008). Vogue UK: Coco Chanel. Retrieved August 23, 2017 from http://www.vogue.co.uk/article/coco-chanel-biography

Drishti, L. (2015). An interior with Mashrabiya at Amber Palace in Rajasthan, India. Retrieved April 22,

2016 from http://undercoverdiva.tumblr.com/post/5641983258/

amber-palace-rajasthan-india

Fathy, H. (1986). Natural Energies and Vernacular Architecture, Mashrabiya (pp. 46-49). Chicago, USA: The University of Chicago Press.

Fernando, N. A. (2008). Culture and identity in urban streets: A case study of Chinatown, New York City. Milwaukee: The University of Wisconsin.

Ficarelli, L. (2008). The Domestic Architecture in Egypt between Past and Present. The Passive Cooling in Traditional Construction. In Proceedings of the Third International Conference on Construction History, (Vol.2, pp. 54-72). Cottbus, Germany: University of Technology.

Gelil, N. \& Ali, W. (2014). Traditional Residential Architecture in Cairo from a Green Architecture Perspective. In Proceeding of the International Conference of Art and Design Studies (Vol. 14, pp. 6- 23). Egypt- 6th of October City: October University for Modern Sciences and Arts, MSA University.

Hamilton, L. (2014). Laura Hamilton investigates the Arab designers that are cutting a swathe through the fashion world. Retrieved April 28, 2016 from http://www.surlaterre.me/ultra-couture/

Hay, R. (1863), Views in Kairo. [Illustrations of Cairo]. [CARTER, Owen Browne, artist Book. Adrian Harrington Rare Books Press. England: London. 
Hedayat, A. (2012). Inquiry on Interrelationships Between Architecture and Fashion Design. Master Thesis, Eastern Mediterranean University, North Cyprus.

Hefuna, S. (1997). The Photographer of Woman Behind Mashrabiya. Retrieved April 19, 2016 from https://collections.lacma.org/node/1151329

Jagwani, A. (2016). Gold finish Mashrabiya ring's designer. Retrieved February 12, 2017 from https://www.perniaspopupshop.com/astha-jagwani-gold-finish-mashrabiya-ring-asjc2f1115r10.html

Klein, C. (2015). Calvin Klein Lectures on the Role of Architecture in Fashion. Retrieved July 25, 2017 from https://www.youtube.com/watch?time

_continue $=1 \& v=s G E-O 3 n T k 10$

Kostof, S. (1977). The Architect, Chapter in the History of the Profession. New York: Oxford University Press.

Lafer, S. (2017). How Mondrian Has Been Influencing Pop Culture for 100 years. Retrieved August 14, 2017 from http://www.sleek-mag.com/2017/05/31/mondrian-100-years/

Lampen, J. (2017). Photographer of the Mondrian painting on the City Council of The Hague. Retrieved August 14, 2017 from https://www.theguardian.com/artanddesign /2017/feb/03/dutch-celebrate-mondrian-cladding-the-hague-city-hall

Loschek, I. (2009). When Clothes Become Fashion, Design and Innovation Systems. New York: Berg.

Mario Uboldi Company (2016). Mashrabiya Jewelries. Retrieved 30 April 2016 from https://www.mariouboldi.com/collections/most-popular/products/maab156 https://www.mariouboldi.com/collections/most-popular/products/maah166 https://www.mariouboldi.com/collections/most-popular/products/made146

Meyerhans, A. (2016). Mashrabiya Mask's designer. Retrieved from https://kavyar.com/works/Nx1LvVrC9Uvt

Miles, G. (2008). Skin+ Bones, Parallel Practices in fashion and architecture. London: Somerset House. Retrieved August 20, 2017 from https://www.somersethouse.org.u k/whats-on/skinbones

Morais, J. (2016). FOUNDER\&CEO Founder and CEO of Love Happens Magazine. Retrieved February 12, 2017 from https://www.lovehappensmag.com/blog/about/

Morgan, L. (2016). Tim Gunn on Chanel, The Golden Girls, and Aretha Franklin. Retrieved July 01, 2017 from https://www.architecturaldigest.com/story/tim-gunn-on-project-runway-chanel-the-golden-girls-andaretha-franklin

Mostafavi, M. (2015). Dean and Professor of Design, Harvard GSD.

Pattern in Islamic Art. (2016). An image showing details of the hexagon pattern of Mashrabiya. Retrieved July 24, 2016 from http://patterninislamicart.com

/archive/main/2/ india/ind0630

Poole, B. (2009). Mashrabiya at Alhambra Palace in Granada, Spain. Retrieved June 23, 2016 from https://www.flickr.com/photos/brucepoole/5422052444/in/set-72157623803548685/

Pugh G. \& Knight N. (2008). Elevation: An Epic Fashion Collaboration. Dazed \& Confused. Vol. 2, 66, pp. 4550. 
Quinn, B. (2002). Techno Fashion. London: Berg Publishers.

Sharonne, B. (2014). Fashion by Arch. Zaha Hadid. Retrieved September 14, 2017 from http://bijouxsharonne.blogspot.com/

Tang, K. (2013). Mashrabiya dress designed by Wadha Al Hajri in the Vogue Fashion Dubai Experience at Dubai Mall on October 10, 2013 in Dubai, United Arab Emirates. Retrieved February 15, 2017 from http://www.surlaterre.me/ultra-couture/

Tolba, Y. (2011). An interior view of Mashrabiya at al-Suhaymi House in Cairo, Egypt. Retrieved June 6, 2014 from https://tr.pinterest.com/pin/55535

0197780387612/

Trevis, N. (2015). World OF Wadha. Retrieved April 5, 2016 from https://mojeh.com/fashion/interviews/world-wadha

Valadi, S. (2015). Mashrabiya at alSuhaiymi house in Cairo, Egypt. Retrieved September 19, 2016 from https://www.flickr.com/photos/132084522@N05

/16952841285

Willems, N. (2011). The Guggenheim hat. Retrieved June 14, 2017 from http://irenebrination.typepad.com/irenebrination_notes_on_a/2011/11/page/2/

Woods, L. (2009). Art to Architecture. Retrieved August 21, 2017, from http://lebbeuswoods.wordpress.com/2009/03/05/art-to-architecture/ 